\section{Potential Economic Values of Weather Modification on Great Plains Grasslands'}

\section{EARL A. HAUSLE}

Instructor, 2 Department of Languages and Social Sciences, South Dakota School of Mines and Technology, Rapid City.

\section{Highlight}

Experimental weather modification projects on the Great Plains indicate that selective cloud seeding during the summer months may produce from one-half to one inch of moisture. To determine the potential economic benefits from this amount of moisture long term forage production and meteorological data from three range sites in Kansas were statistically analyzed. Forage production was highly correlated with growing season moisture. On each of the three sites benefit-cost ratios were favorable, ranging from 21.7 to 1 on site one, 6.4 to 1 on site two and 25.2 to 1 on site three, based on a seeding cost of $\$ 0.10$ per acre and a onc-half inch increase in rainfall.

Weather modification projects of the precipitation increase type have become more prevalent in recent years on the Great Plains. Whether these cloud seeding projects are experimental or commercial, little has been done to determine the potential economic cost or gain. It is easy to gen-

1 Received April 19, 1971.

${ }^{2}$ Present position, Assistant Professor (Economics). eralize about benefits if sufficient amounts of precipitation result from cloud-seeding; however, research by the Institute of Atmospheric Sciences (IAS) of the South Dakota School of Mines and Technology at Rapid City, South Dakota, indicates that increases in precipitation, during the growing season, may be in the one-half to one inch range. Their research also indicates that selective seeding is required to generate even these modest increases. This is in an area where average annual precipitation is 14.71 inches at the United States Weather Bureau station near Rapid City, South Dakota.

Success of cloud seeding to increase precipitation is indicated by studies of two South Dakota projects using target control analysis, according to meteorologist E. I. Boyd of IAS. June and July seeding from 1966 through 1970 increased precipitation from 8 to $12 \%$ (approximately .5 of an inch) in Perkins and Corson counties while May through August seeding in Pennington, Custer and Fall River counties from 1965 through 1970 increased precipitation by $7 \%$ (approximately .75 of an inch.)

\section{Methods and Procedures}

To avoid technological variables such as improved seed varieties, tillage methods and fertilizers, this study was primarily concerned with data on native range grasses from various Great Plains expcriment stations.

The analytical methods used to determine the possible effect of precipitation on native range grasses employed linear correlation, multiple regression and analysis of variancc. 
Two methods were used to determine economic benefits. First, a per-ton value for wild hay was assumed as a selling price and this, in turn, was reduced to a price per pound for the hay produced, and the value of the additional amount produced was compared to the assumed cost of weather modification to arrive at a bencfit-cost ratio. This method is used only by way of illustration, due to variations in selling price as well as to the limitation of selling price as an adequate measure of the value of wild hay to the producer.

The second method uses animal units of grazing where $1,000 \mathrm{lb}$. of body weight is considered an animal unit. Using the cost per month for an animal unit of grazing of $\$ 4.00$ for South Dakota and $\$ 4.50$ for Kansas and the other states, estimates of the value of any additional forage produced can be more accurately predicted.

The costs of cloud seeding are based on figures from two sources, the Santa Clara County California project and estimates by staff members of the Institute of Atmospheric Sciences, who have had considerable experience with both commercial and experimental weather modification projects.

Numerous studies made for the purpose of providing ranchers with some method of predicting proper stocking rates on pastures have frequently shown that there is a high correlation between precipitation and forage yields. Currie and Peterson (1966) attribute from 88 to $97 \%$ of differences in yield on the Front Range of Colorado to precipitation; Smoliak (1956) finds the precipitation and forage yield in southeastern Alberta, Canada, to have a correlation coefficient of .86 ; while Noller's (1968) research in Wyoming shows that $84 \%$ of the variation in total forage yield was due to precipitation.

While these studies show the relationship between precipitation and forage production, the use of stepwise regression analysis by the researchers showed that the time when precipitation fell, as well as the amounts, was important. Currie and Peterson (1966) showed that April through August precipitation is the most important factor in total forage production, while Smoliak (1956) found that May plus June precipitation was the most significant, and Noller (1968) found spring precipitation more closely related to total forage production than any other factor.

All three of the previously cited studies also cite similar findings by other researchers. This indicates that other factors such as hours of light, wind, temperature, and so forth, may not be as important in forage production as is precipitation occurring at certain times of the year. Noller found seasonal mean temperature, wind velocity, and the amount of sunlight to be negatively correlated with the production of forage.

Many studies, including some cited here, used data obtained from observations covering a relatively short period of time. In order to have greater confidence in the study, longer term studies are needed. Information has been collected since 1941 on three different native grassland habitats at Fort Hays Kansas State College. These three sites are within a one mile radius of the Fort Hays Experiment Station where climatological data are collected. The three plots from which the foragc is harvested are meter plots and the data on forage yield are given in pounds per acre. The three sites are called Shortgrass Habitat, Little Bluestem Habitat and Lowland Habitat respectively. They will be referred to as sites one, two and three respectively, hereafter. The data are broken down into shortgrass, mid-
Table 1. Correlation coefficients for seasonal and annual precipitation and forage production on the three Kansas plots.

\begin{tabular}{lccc}
\hline \hline & \multicolumn{3}{c}{ Cor. coef. } \\
\cline { 2 - 4 } \multicolumn{1}{c}{ Period for precip. } & $\begin{array}{c}\text { Short- } \\
\text { grass }\end{array}$ & $\begin{array}{c}\text { Little } \\
\text { Bluestem }\end{array}$ & $\begin{array}{c}\text { Low- } \\
\text { land }\end{array}$ \\
\hline Fall (Oct.-Dec.) & 0.32 & 0.03 & 0.20 \\
Winter (Jan.-March) & 0.37 & 0.42 & 0.14 \\
Spring (April-June) & 0.48 & 0.29 & 0.40 \\
Summer (July-Sept.) & 0.40 & 0.56 & 0.46 \\
Growing season (April-Sept.) & 0.62 & 0.57 & 0.60 \\
Previous growing season & 0.09 & 0.06 & 0.01 \\
Annual & 0.67 & 0.57 & 0.59 \\
\hline
\end{tabular}

grass, total grass, forbs, weeds and total vegetation, but this analysis uses total vegetation only. For the twenty-six year period from 1941 through 1966 the average yield on sitc one was 2638 with a low of 564 and a high of 4893 , while the site two average was 1767 with a low of 419 and a high of 3480 and the site three average was 3858 with a low of 168 and a high of 6418 .

Seasonal precipitation and temperature information were furnished by the Fort Hays Experiment Station and forage production data by the Fort Hays Kansas State College.

\section{Results}

Statistical analysis to determine the relationship between precipitation and yield of total vegetation on the three sites revealed that there was no significant relationship between the total yield and precipitation occurring during the previous growing season, fall, winter, spring or summer. Only current growing season precipitation showed a significant relationship for all three sites. The current growing season included the six month period April through September (Table l).

While the multiple regression analysis shows that the precipitation of the entire period April through September is significant for predicting yields of total vegetation, it also clearly shows that precipitation received during June and August is much more important than that received during any other month or months during the growing season (Table 2).

Table 2. Correlation coefficients for monthly precipitation and forage production on the three Kansas plots.

\begin{tabular}{lccc}
\hline \multirow{2}{*}{ Month } & \multicolumn{3}{c}{ Cor. coef. } \\
\cline { 2 - 4 } & Shortgrass & Little Bluestem & Lowland \\
\hline April & 0.10 & -0.43 & 0.06 \\
May & 0.36 & 0.25 & 0.12 \\
June & 0.42 & 0.38 & 0.48 \\
July & 0.33 & 0.42 & 0.22 \\
August & 0.55 & 0.27 & 0.47 \\
September & -0.08 & 0.21 & 0.18
\end{tabular}


The regression equation derived from the relationship of yield to growing season precipitation for each of the three sites is as follows:

(1) $\mathrm{Y}=612+578 \mathrm{X}$

(2) $\mathrm{Y}=771+170 \mathrm{X}$

(3) $\mathrm{Y}=1693+673.86 \mathrm{X}$

where $\mathrm{Y}=$ estimated yield of forage in pounds per acre and $\mathrm{X}=$ the inches of precipitation received.

Assuming that the amount of precipitation could be increased in the area by cloud seeding by as much as one-half inch, the yield of forage in pounds per acre could be increased on the three sites as follows: (1) 289, (2) 85 , and (3) 336 .

\section{Economic Evaluation}

The Santa Clara County, California, weather modification project contains all of the elements necessary to a sound and successful cloud seeding program: (1) ground support and control, (2) seeding method and capability, (3) some evaluation of results, and (4) adequate funding.

The project is controlled from a field office which houses the radar, radio, telephone and meteorological data receiving equipment. This unit plus the manpower needed to operate the control unit provides the required direction and control and represents the fixed cost of this or any other properly established program. Most of the seeding is done from 22 ground based generators, but aircraft have been used for some seeding.

The target area is quite small, covering only 454,000 acres. The annual cost of seeding has averaged $\$ 26,949$, which amounts to $\$ 0.06$ /acre. As shown by Kriege (1968) the program is operated for about four months each year.

On the Great Plains, the airplane replaces the ground generator as the mainstay of cloud seeding, although ground generators may also be used. The cost of minimum ground support and control is estimated at $\$ 25,000$ for a four month program. For North and South Dakota the cost of the aircraft and pilot is estimated at $\$ 25,000$ per aircraft.

Assuming the optimum coverage for a single aircraft to be approximately 800,000 acres, the total cost of the program is $\$ 50,000$ or $\$ 0.06 /$ acre. If the size of such a project were reduced to the size of the Santa Clara project, the cost would be increased to $\$ 0.11$ /acre.

A second aircraft could be added at the same cost as the first one, but with no increase in the cost of ground support and control. The area covered could be doubled to a total of 1,600,000 acres, or 2,500 square miles. The total costs would be $\$ 75,000$, or approximately $\$ 0.04$ acre. The lowered costs reflect some economies of scale which will, however, begin to rise with the addition of a third aircraft seeding within the same $1,600,000$ acres, even if ground support costs were to remain the same.

The preceding discussions of weather modification costs make clear the possible variations in cost per acre due to the type of seeding, size of the project, and so forth. Since the costs for seeding on the Great Plains were estimated operational costs, with no allowances for overhead costs, it is necessary to assume a cost. The cost assumed for seeding on the Great Plains is $\$ 0.06 /$ acre.

The lowest predicted increase in yield based on the data provided by Fort Hays Kansas State College was $85 \mathrm{lb}$./acre on site two. If this hay was sold at $\$ 20 /$ ton or $\$ 0.01 / 1 b$. and the cost of obtaining the additional one-half inch of moisture is assumed to be $\$ 0.06$ /acre the benefit-cost ratio is 14.1 to 1 .

A more accurate method of computing benefitcost ratios would be to assume that the forage would be grazed rather than harvested and sold as hay. Using the animal-unit-month method, with an animal unit being the amount of forage required by a 1,000 lb. animal for one month, which is considered to be approximately $20 \mathrm{lb}$. of air dried forage per day or $600 \mathrm{lb} . / \mathrm{month}$, the days of grazing provided by any additional forage produced can be calculated. On the basis of animal units of grazing per month, a value of $\$ 4.50$ per each monthly unit can be assumed. This is approximately $\$ 0.15 /$ day.

On this basis, the lowest production from site one would provide 14.45 days of grazing; site two, 4.25 days; and site three, 16.8 days. The benefitcost ratio, assuming a seeding cost of $\$ 0.10 /$ acre, would be 21.7 to 1 on site one, 6.4 to 1 on site two, and 25.2 to 1 on site three.

For an increase of one inch in growing season precipitation, the forage production on the three sites as indicated by the regression equation would be: (1) 578, (2) 170, and (3) 673.86. Benefit-cost ratios based on grazing would be for site one 43.35 to 1 , site two 12.75 to 1 , and for site three 50.54 to 1 .

Since these production figures are for only one area, and each area must be evaluated separately, cost-benefit ratios may be applied to the production figures of other researchers in an attempt to discover whether or not modest increases in precipitation could be considered to be worth the cost of weather modification programs.

Noller (1968) found that production on two blue grama areas in Wyoming yielded 71.6 lb. of forage/inch of rainfall. Assuming the same animal unit cost per month, the benefit-cost would be 8.95 to 1 .

Hutchings (1953) found that in the southern Intermountain ranges of $U$ tah an inch of precipitation increased forage production by $46 \mathrm{lb}$./acre. Even 
this relatively low production would provide a bencfit-cost ratio of 5.75 to 1 .

Thomas and Osenbrug (1964) found that in western South Dakota one inch of precipitation produced $104 \mathrm{lb}$. of bromegrass-crested wheatgrass hay/acre. The favorable benefit-cost ratio in this case would be 13 to 1 .

\section{Potential Gains in South Dakota}

The South Dakota Agriculture, Crop and Livestock Reporting Service bulletin for 1968 shows the average yield per acre of wild hay in the state as three-fourths of a ton. This figure is for the years 1962 through 1966, and mean total annual yield for the period was $1,572,000$ tons.

The lowest mean yield of the three Kansas plots used for this study was $1767 \mathrm{lb}$./acre on two sites. The predicted increase resulting from one-half inch of additional precipitation for this plot was $85 \mathrm{lb}$./ acre. This is an increase of $4.8 \%$ in weight.

If the rate of increase in production was the same for South Dakota in terms of percent, this would mean an increase of $72 \mathrm{lb}$., based upon the 1,500 lb./acre average yield previously cited. This much additional forage would provide an additional 3.6 animal unit days of grazing valued at approximately $\$ 0.13 /$ day. This would be a total of $\$ 0.47$ / acre and the benefit-cost ratio would be 7.8 to 1 .

With an average of 2,800,000 acres in wild hay in South Dakota from 1962 through 1966, the total value of an additional half inch of precipitation in additional forage production alone could be as much as $\$ 1,512,000$.

Even if the percent of increase is reduced from $4.8 \% /$ acre to $3 \% /$ acre the benefits will be substantial. It would provide an increase of $45 \mathrm{lb}$./ acre which would provide 2.25 animal unit days of grazing at a value of approximately $\$ 0.34$ /acre. The benefit-cost ratio is 5.6 to 1 and the total value of the additional forage produced would be $\$ 945,000$.

\section{Conclusion}

Evidence from successful long term operational rain increase programs such as the Santa Clara County project and numerous scientific weather modification projects clearly indicates that under certain conditions precipitation can be increased through cloud seeding.

It is possible to predict the amount of grass and grain production which would be likely to result from increased precipitation by statistical methods where long term production and climatological data are available.

In each case available to the author, all of which were cited within the body of this paper, cost benefit ratios were favorable, but different locations made the results vary widely, as should be expected.

An assessment of potential costs as well as potential increases in production should be made before weather modification projects of the operational type are undertaken. Particular attention must be paid to local climatology, the time at which rain would be most beneficial for the variious crops, since there could be times when precipitation could be most helpful to one type of crop and quite harmful to another, and finally, to costs when compared to expected benefits.

There is considerable evidence that economic benefits from weather modification aimed at increasing precipitation have a great potential on the Great Plains.

\section{Literature Cited}

Currie, Pat O., and Geraldine Peterson. 1966. Using growing-season precipitation to predict crested wheatgrass yields. J. Range Manage. 19:284-288.

Hutcinings, Selar S., and George Stewart. 1953. Increasing forage yields and sheep production on Intermountain winter ranges. U.S. Dep. Agr. Circ. No. 925, $63 \mathrm{p}$.

Kriege, Daniel F. 1960. Operational cloud seeding. A paper presented at the California Section Meeting, American Waterworks Association, Monterey, California, April 1960, 3 p.

Noller, GaRY L. 1968. The relationship of forage production to precipitation, cover and soils in North Central Wyoming, Ph.D. thesis, Univ. of Wyoming, Laramie, Wyoming.

Smoliak, S. 1956. Influence of climatic conditions on forage production of shortgrass rangeland. J. Range Manage. 9:89-91.

Thomas, James R., And A. Osenbrug. 1964. Interrelationships of nitrogen, phosphorus and seasonal precipitation in the production of bromegrass-creasted wheatgrass hay. U.S. Dep. Agr., Prod. Res. Rep. No. 82. 19 p.

What do we want the Society to be? We have two alternatives. First, we can ride along on our laurels and become a society of paper-readers, and technique-perfectors forever doomed to mediocrity. Or, second, we can accept the challenges presented by the objectives of our Society, so ably stated in our Constitution, and become a constructive force in molding the management of the grassland resources and in shaping the future of this country. (Joseph $F$. Pechanec. J. Range Manage. 2:39) 